\title{
Adoption of Modern Hydrogen Technologies in Rail Transport
}

\author{
Paweł Stobnicki', Dawid Gallas ${ }^{1 *}$ \\ 1 Łukasiewicz Research Network - Institute of Rail Vehicles “TABOR”, ul. Warszawska 181, 61-055 Poznań, Poland \\ * Corresponding author's e-mail: dawid.gallas@tabor.lukasiewicz.gov.pl
}

\begin{abstract}
Many new zero-emission propulsion technologies are being developed today due to the need to reduce the atmospheric carbon dioxide emissions. The impact of the transport sector on the environment drives a need for innovation, including innovation in the rail transport sector specifically. At the TRAKO fair of rail vehicles the newest technological solutions have been presented. These new vehicles are expected to take over the rail transport sector in the coming decades. Many of the presented solutions and prototypes focused on using hydrogen as fuel for a system of hydrogen fuel cells, which are then used to produce the electricity needed to drive the vehicle. The development of hydrogen fuel technologies in vehicle drives in recent years allowed for a set of new solutions to appear for all types of rail vehicles and applications. Hydrogen powered rail vehicles for transporting cargo, passengers, and shunting vehicles have been shown. This article provides a discussion of the newest hydrogen solutions and vehicles sent to the market. It was determined that the adoption of such solutions will be mainly restricted by the relative cost of the hydrogen fuel rather than the vehicles or fuel cell technologies themselves. The cost of hydrogen production, when powered by renewable Energy sources to enable reduced carbon dioxide emissions, would need to be reduced to at least $\$ 2.50 / \mathrm{kg}$ of fuel in order to satisfy the requirements for widespread adoption.
\end{abstract}

Keywords: exhaust emissions, hydrogen fuel, fuel cells, rail transport, hydrail.

\section{INTRODUCTION}

Due to the growing demand for ecological transport solutions many innovative products and new technologies are continuously introduced. As a result of the development strategy, adopted by the EU member states, aimed at building a net zero emissions transport grid the current vehicle market, of both road and rail vehicles, is in the first stages of its most significant change since the introduction of the combustion engine. No other propulsion technology since has been planned and implemented as thoroughly and consistently as the new shift towards low and zero emissions technologies. The main steps being taken with the aim of accomplishing this change include a complete remodeling of the transport sector, using state-of-the-art technologies, into a transport system network that can be considered as having net zero emissions. This is a huge undertaking, especially considering the fact, that many of the technologies that are expected to outcompete the conventional combustion engines are still some development away from being commercially viable. Nevertheless, such goals and efforts are deemed as necessary. The EEA report on the Air Quality in Europe [Report 2020] states that the share of urban population in the EU-28 group of countries that were exposed in 2018 to toxic compounds in concentrations exceeding the European norms reached as high as $15 \%$ for larger particles (PM10) and for benzo(a)pyrene (BaP), while for fine particles (PM2.5) and nitrogen oxides $\left(\mathrm{NO}_{\mathrm{X}}\right)$ this share was $4 \%$. This means that a significant portion of the urban population in the EU is constantly in the presence of excessive concentrations of highly toxic substances in the air, which can cause cancer, lung disease, heart disease and many more health problems. On a positive note the mass of toxic substances released into the atmosphere in EU member states has decreased, despite continued economic growth, which indicates that the goals set by the EU are feasible and can be reached (Fig. 1). However, the rate of this 


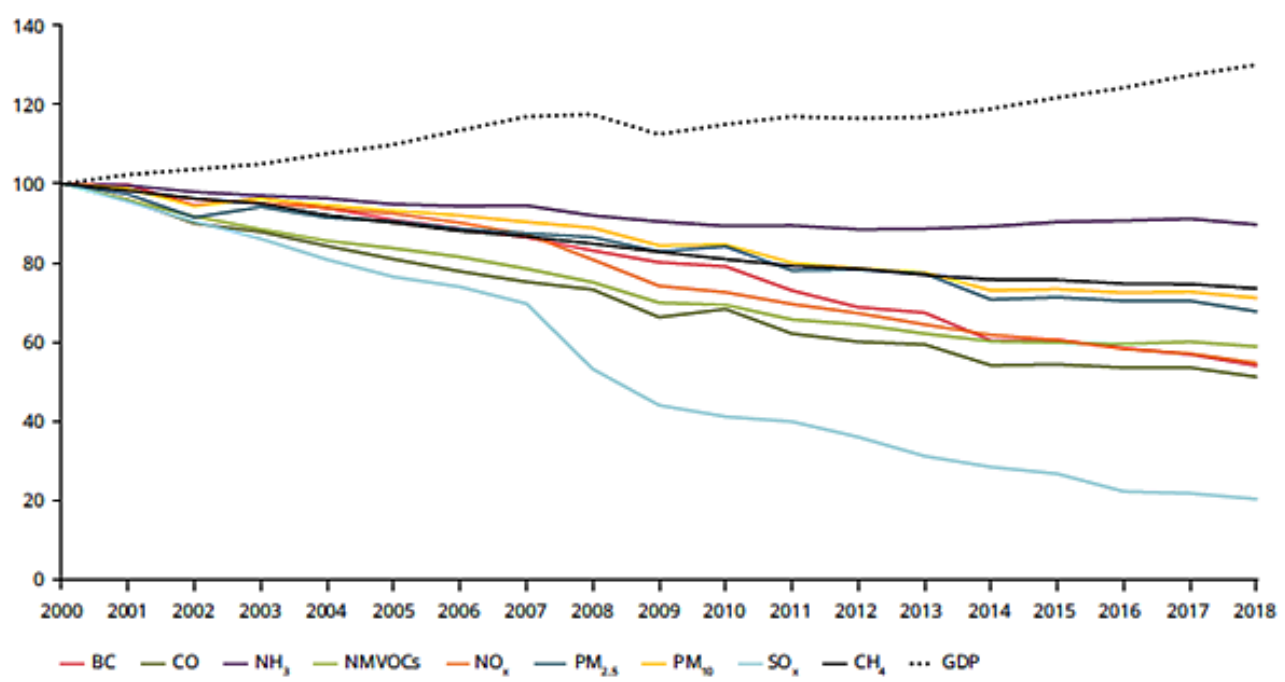

Figure 1. Relative change in the emissions of toxic compounds in EU-28 since 2000 (BC - soot, CO - carbon monoxide, $\mathrm{NH}_{3}$ - ammonia, NMVOCs - non-methane volatile organic compounds, $\mathrm{NO}_{\mathrm{X}}-$ nitrogen oxides, $\mathrm{PM}_{2.5}$ - particulate matter under $2.5 \mu \mathrm{m}, \mathrm{PM}_{10}$ - particulate matter in the range $2.5-10$ $\mu \mathrm{m}, \mathrm{SO}_{\mathrm{X}}-$ sulfur oxides, $\mathrm{CH}_{4}-$ methane, GDP - cumulative Gross Domestic Product) [Report 2020]

decrease in emissions is too slow to allow reaching a net-zero emissions economy on its own within any reasonable time frame, which also serves to underline the importance of urgent and focused steps being taken in the effort of reducing these emission values.

\section{Hydrogen powered rail vehicles}

New vehicle drive technologies that are currently in development tend to move towards alternative, pro-ecological, and zero-emission solutions [Oldknow et al. 2021, Daszkiewicz et al. 2017]. The most common and widespread technology that falls into that category are electric rail vehicles. These vehicles require for the rail lines to be electrified, while the share of railways that are electrified can vary greatly depending on the EU country considered. Many EU member states plan on expanding their railway electrification, one of such examples is Germany, which plans to increase their share of electrified rail lines from $52 \%$ to $70 \%$ in the coming decades [Railway Report 2020]. Due to the high financial costs of railway electrification the popular and proposed alternative solutions usually consider propulsion technologies that allow the vehicles to operate on non-electrified lines. Most hybrid rail vehicles can be considered as belonging to this category, where operations outside of the range of electrification can be performed using the conventional combustion engines. Another possible solution is using electric locomotives equipped with Energy storage systems, which allow them to temporarily operate outside of the electric traction. This strategy has mostly been adopted by Scandinavian countries, mainly Denmark and Norway. Some American companies have offered solutions using electric locomotives, powered with batteries, as an additional propulsion system in a larger conventional freight consists. Such was the intended application of the FLX Drive freight locomotive produced by Wabtec [https://www.wabteccorp. com/locomotive/alternative-fuel-locomotives/ flxdrive] which, when included in a larger consist, enables the whole set to utilize the $2400 \mathrm{kWh}$ of power stored in its batteries, which allows the $3230 \mathrm{~kW}$ engine to operate at full power for about 30 minutes (Fig. 2).

Innovative drive systems face many barriers to widespread use due to the limited level of

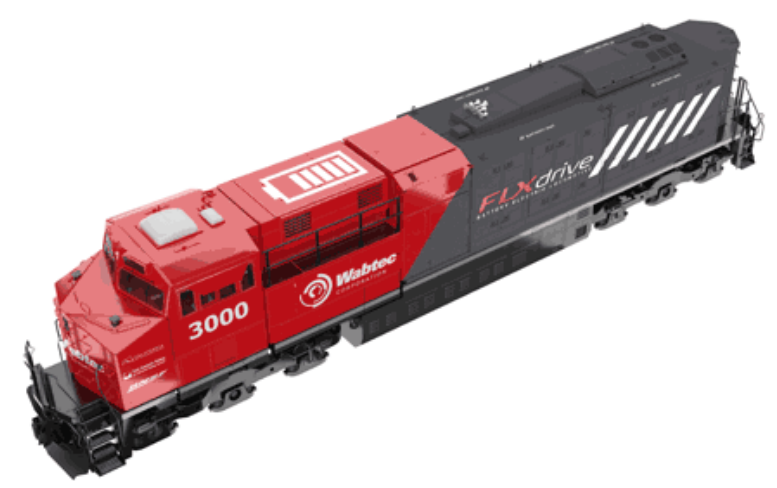

Figure 2. FLX Drive freight locomotive produced by Wabtec [5] 
their development. Hence the use of alternative drive systems may be impossible for applications that are required to maintain a certain level of reliability. As a result most solutions that are being investigated or made commercially available include hybrid drive systems [Singh et al. 2019]. One such example is the shunting locomotive GG20B (known as Green Goat) [https://locomotive.fandom.com/wiki/RailPower_GG20B] with a hybrid drive system (combustion-electric), for which a hydrogen fuel cell variant marked HH20B (Fig. 3) has been proposed [http://www.trainweb. org/greengoats/bnsf/1205.html]. An example of a purely hydrogen solution would be the vehicle produced by PESA Bydgoszcz S.A. in cooperation with PKN Orlen. Thorough modernization of the old and tried shunting locomotive SM42 a new variant labelled SM42 6Dn (Fig. 4) has been designed, equipped in four $180 \mathrm{~kW}$ as well as two sets of hydrogen fuel cell systems (Fig. 5), each of which can produce $85 \mathrm{~kW}$ of continuous power. Combined with an on-board energy storage system with a combined capacity of $160 \mathrm{kWh}$ this makes it possible for the vehicle to operate using hydrogen fuel, stored in tanks with a combined capacity of $175 \mathrm{~kg}$ of hydrogen (Table 1). Such a solution has been proposed for passenger transport in the form of Alstom's Coradia iLint (Fig. 6). This two-unit railcar is reported to be able to travel over $1000 \mathrm{~km}$ and with a maximum travel speeds of $140 \mathrm{~km} / \mathrm{h}$, where each of the vehicle units is equipped with a hydrogen storage tank system with a capacity to store $94 \mathrm{~kg}$ of hydrogen fuel. The hydrogen is used to power the fuel cells of the vehicle which have a power of $314 \mathrm{~kW}$ (Table 2). For freight locomotives a respective hydrogen solution is still in early development stages, since it would require a much greater power output than the passenger or shunting vehicles. One of the solutions currently in development is a new hydrogen freight locomotive,

Table 1. Operating parameters of the SM42 6Dn hydrogen shunting locomotive

\begin{tabular}{|l|c|}
\hline \multicolumn{1}{|c|}{ Parameter } & Value \\
\hline Max speed & $90 \mathrm{~km} / \mathrm{h}$ \\
\hline Service mass & $<70 \mathrm{t}$ \\
\hline Hydrogen fuel cells power & $85 \mathrm{~kW}$ x2 \\
\hline Expected fuel consumption & $<0.08 \mathrm{~kg} / \mathrm{kWh}$ \\
\hline DC power supply voltage & $<800 \mathrm{~V}$ \\
\hline Intermediate battery capacity & $>160 \mathrm{kWh}$ \\
\hline Hydrogen fuel tanks capacity & $175 \mathrm{~kg}$ \\
\hline Fuel cells operating temperature & $-40^{\circ} \mathrm{C}$ to $+85^{\circ} \mathrm{C}$ \\
\hline
\end{tabular}

which is to be a repowered version of an already existing freight locomotive used by Canadian Pacific. This is to be achieved by equipping a locomotive with 6 hydrogen fuel cell systems produced by the company Ballard, which would result in a total power output of $1200 \mathrm{~kW}$. Because the mark and model of the combustion engine locomotive that is to serve as basis for this repowering process by

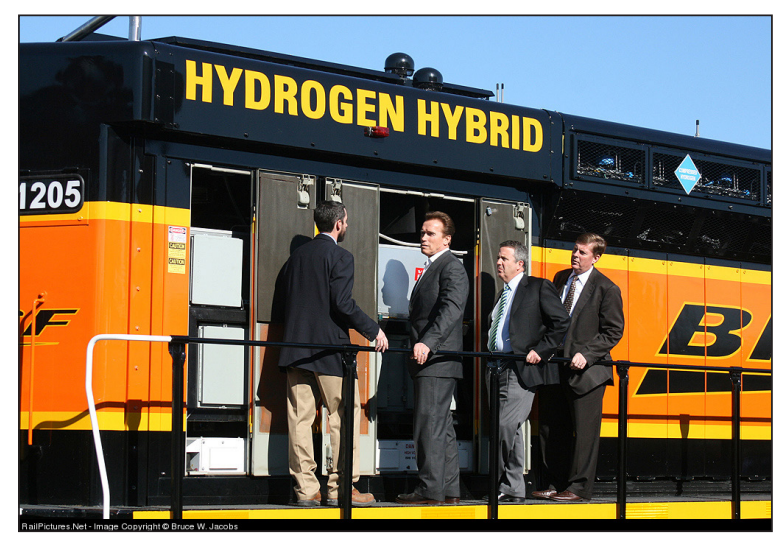

Figure 3. The hydrogen variant of the electric shunting locomotive Green Goat marked as HH20B presented to the Californian Governor [https://trainoftheweek. blogspot.com/2010/02/bnsf-hh20b.html]

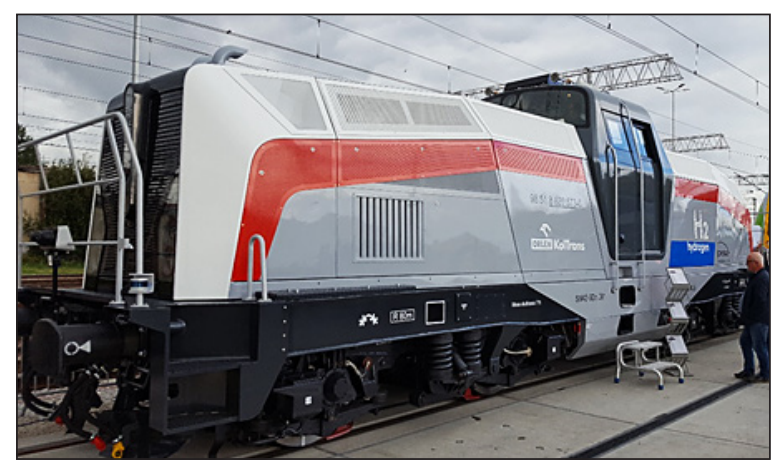

Figure 4. Hydrogen locomotive SM42 6Dn as presented at the TRAKO 2021 rolling stock fair

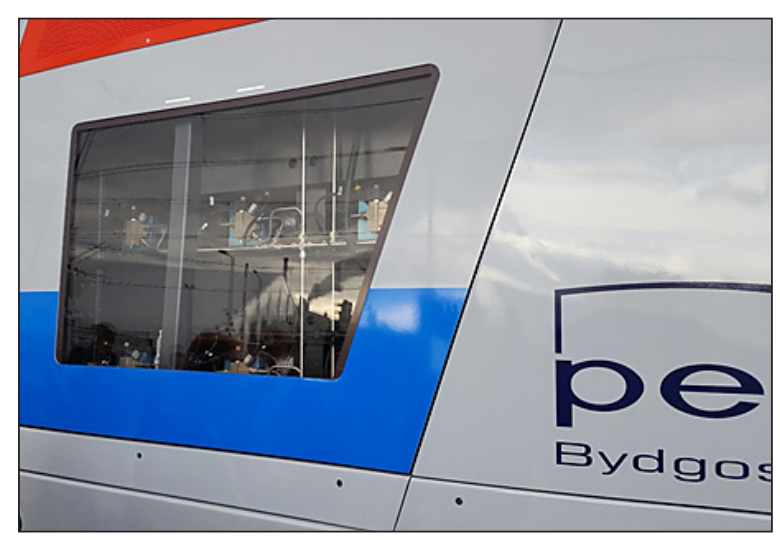

Figure 5. Hydrogen fuel cells powering the SM42 6Dn locomotive produced by PESA Bydgoszcz 


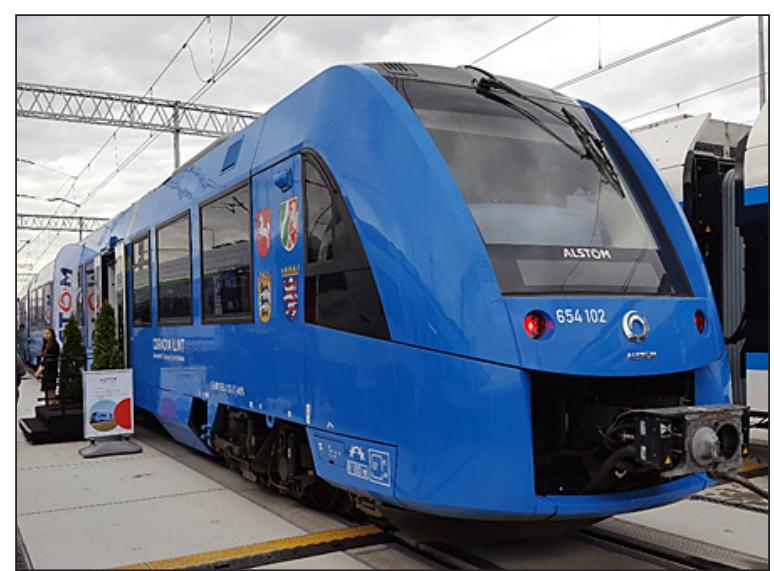

Figure 6. Hydrogen passenger vehicle Coradia iLint produced by PESA Bydgoszcz

Table 2. Operating parameters of the Coradia iLint vehicle

\begin{tabular}{|l|c|}
\hline \multicolumn{1}{|c|}{ Parameter } & Value \\
\hline Max speed & $140 \mathrm{~km} / \mathrm{h}$ \\
\hline Range on full tank & $1000 \mathrm{~km}$ \\
\hline Service mass per unit & $49 \mathrm{t}$ \\
\hline Hydrogen fuel tanks capacity & $94 \mathrm{~kg}$ \\
\hline
\end{tabular}

Canadian Pacific to become the new hydrogen solution is still unknown, the comparison performed in the article was done using the freight locomotive EMD SD40-2, which is a staple vehicle in Canadian Pacific's rolling stock (over 500 locomotives of this model are used) [http://www.cprdieselroster. com/Index.htm].

\section{Hydrogen fuel cell technologies}

One of the primary issues arising from the use of hydrogen fuel cells in vehicles is the limited continuous power they provide. The displacement of conventional combustion engines with fuel cell stacks resulted in a decrease in vehicle power in each of the considered cases (Table $3)$. In the case of the Coradia iLint vehicle its power generation using fuel cells is only $54 \%$ of the vehicle power in the combustion engine variant (Coradia Lint). Similarly for the previously planned repowering of a locomotive using a set of Ballard fuel cells, its power after repowering was expected to reach about $54 \%$ of the lowest powered combustion engine variant. The solution offered by PESA in the form of a hydrogen powered shunting locomotive SM42 $6 \mathrm{Dn}$ is to have only $21 \%$ of the original power value of the base conventional locomotive, the SM42 6Dk. Such variation in the power provided to the drive system indicate a significantly different operating properties, characteristics, performance and capabilities of these new hydrogen vehicles when compared to their conventional counterparts. This means, that the range of real utility provided by these new vehicles will be much more narrow than for the older and existing solutions.

Many technologies of hydrogen powered fuel cells exist, such as phosphoric acid fuel cells, solid acid fuel cells, alkaline fuel cells, solid oxide fuel cells, molten carbonate fuel cells, or a fuel cell using a proton exchange membrane (proton exchange membrane fuel cell). In automotive industry the proton exchange membrane variant is the most commonly used (abbreviated to PEMFC). These fuel cells operate in the temperature range of $70-150{ }^{\circ} \mathrm{C}$ and at a pressure ranging from 0.1 to $1.0 \mathrm{MPa}$. The Energy generated by the reactions taking place in the fuel cells which is then sent to the on-board batteries can be described using the equation:

$$
E=m \times H \times \eta_{F C} \times \eta_{B T} \times \eta_{C V}
$$

where: $m$ - hydrogen mass, $H$ - hydrogen combustion energy $(33.2 \mathrm{kWh} / \mathrm{kg}), \eta_{F C}$ - fuel cell efficiency, $\eta_{B T}$ - battery efficiency, $\eta_{C V}$ - alternator efficiency

In such a solution the efficiency of the fuel cell $\eta_{F C}$ is described as being proportional to the voltage $\mathrm{V}$ of the whole fuel cell stack, described

Table 3. Power generated by the drive units of the new hydrogen rail vehicles as compared to the power provided by their closest variants using combustion engines

\begin{tabular}{|c|c|c|c|c|}
\hline Locomotive model & Propulsion system & Engine power/fuel cell power $(\mathrm{kW})$ & Total power $(\mathrm{kW})$ & \multirow{2}{*}{ Manufacturer } \\
\hline SM42 6Dk & Combustion engine & $2 \times 405$ & 810 & \multirow{2}{*}{ PESA } \\
\cline { 1 - 4 } SM42 6Dn & Hydrogen fuel cells & $2 \times 85$ & 170 & \multirow{2}{*}{ Alstom } \\
\hline Coradia Lint & Combustion engine & $3 \times 390$ & 1170 & \multirow{2}{*}{ EMD } \\
\hline Coradia iLint & Hydrogen fuel cells & $2 \times 314$ & 2240 & Ballard \\
\hline EMD SD40-2 & Combustion engine & 2240 & 1200 & \\
\hline
\end{tabular}


using the relation [Barbir 2005], where the lower calorific value of hydrogen is assumed:

$$
\eta_{F C}=\frac{V}{1,254}
$$

The principles of operation of PEMFC type hydrogen cells includes the dissociation of hydrogen $\left(\mathrm{H}_{2}\right)$ to an electron and a proton as a hydrogen ion $\left(\mathrm{H}^{+}\right)$, where the electron is sent away into the circuit. Then the hydrogen ions (being just protons) pass through the proton exchange membrane to reach the other side of the fuel cell, while their electrons $\left(\mathrm{e}^{-}\right)$take the long way around through the electric circuit where their flow is used to generate energy. Hydrogen ions reach the cathode where atoms of oxygen $\left(\mathrm{O}^{-}\right)$are waiting to combine with them after being dissociated from the incoming oxygen molecules $\left(\mathrm{O}_{2}\right)$ also combining back with the electrons coming from the circuit. Finally, the resulting molecules of water $\left(\mathrm{H}_{2} \mathrm{O}\right)$ are created as a product of the cell's operation and released outside the system. This process was simplified into graphical form in Figure 7.

Operation of fuel cells, aside from useful power, generates losses in the form of heat. Even though the operating temperature of such fuel cells is $70{ }^{\circ} \mathrm{C}$, the waste heat generated by them still needs to be drained and dumped in order to prevent overheating. This heat can, however, be used to heat the vehicle, its temperature sensitive elements, or even recovered through the use of thermoelectric generators and turned back into electricity. There are numerous further improvements and solutions that could synergize with the use of hydrogen fuel cells, but due to the novelty of this technology most of those are still in need of further development. The efficiency of fuel cells depends on their type. Currently, the most efficient furl cell type are the alkaline fuel cells (reaching electric energy generation efficiencies of even $60 \%$ ). It is, however, the PEMFC type fuel cells that are most popular in transport solutions, which in spite of their lower efficiency are characterized by smaller size and lower mass compared to other solutions. Due to the importance of reducing size and mass of systems and devices in vehicles the PEMFC type cells won out over the alkaline fuel cells in such applications.

\section{Development and further applications of hydrogen fuel cells}

The increase in the prevalence of new fuel cell technologies in transport results directly from the decrease in their price, along with their rising reliability. The cost per kilowatt of power for the newest iterations of fuel cells has been a $30 \%$ reduction from their price point in 2006 (Fig. 8). Lower price and greater availability, compounded by political efforts towards cleaner transport, have led to an increased competitiveness of fuel cells. Considering the current EU zero net emissions targets by 2050 and the European Green Deal [https://eur-lex.europa.eu/legal-content/PL/TXT/PD

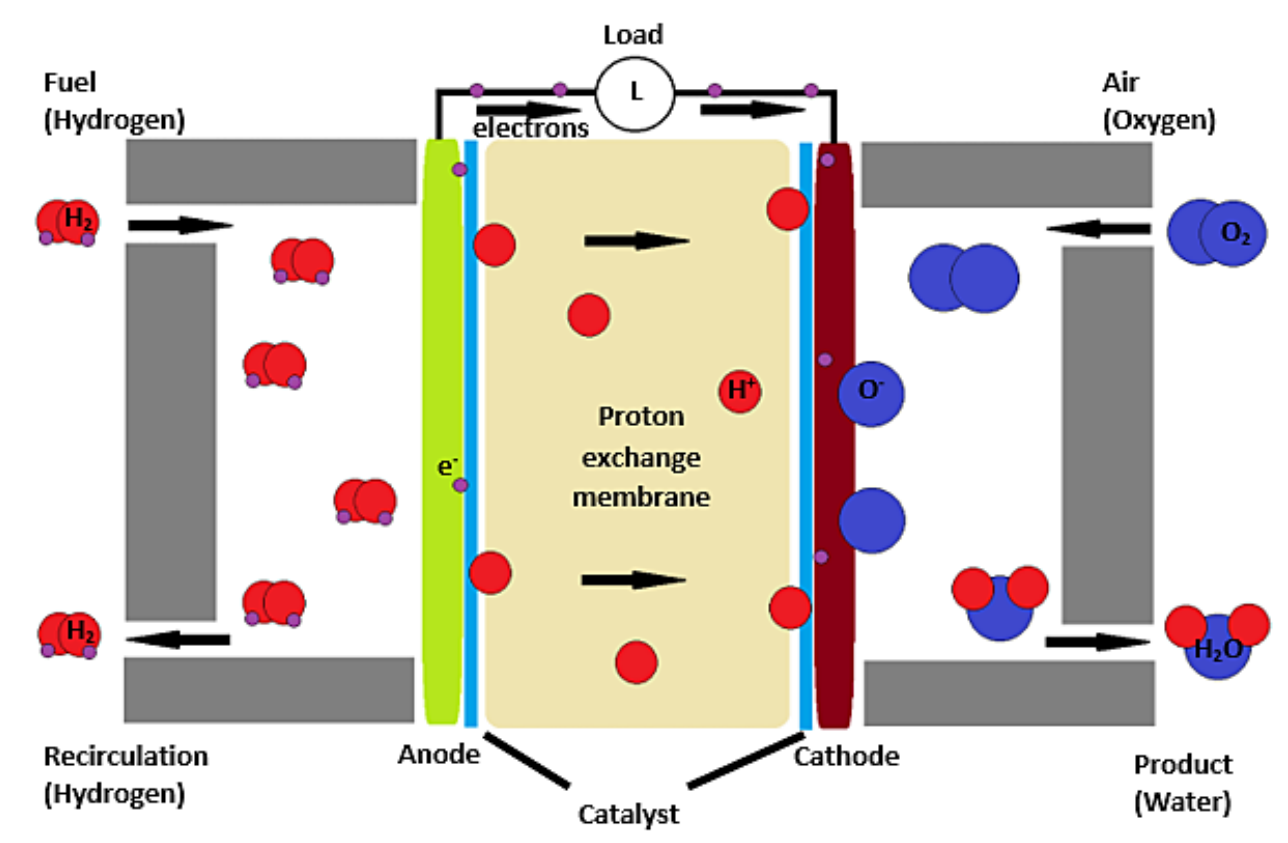

Figure 7. Principle of operation of a PEMFC type of fuel cell 


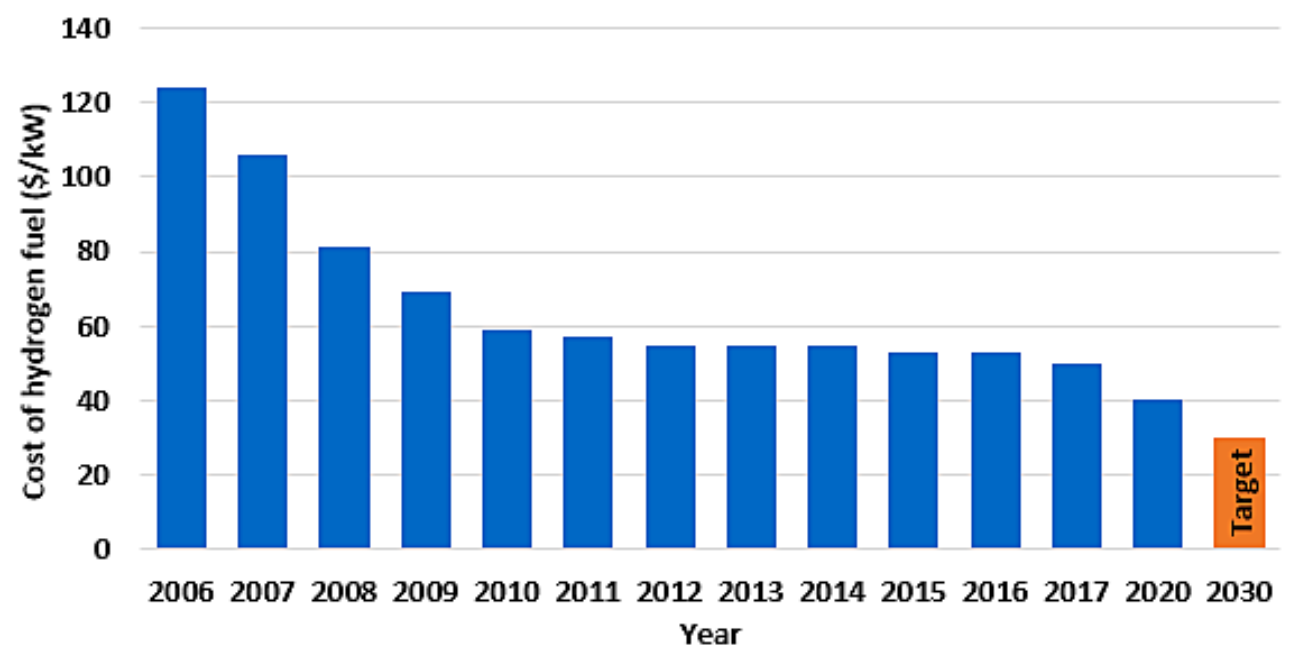

Figure 8. Changes in the costs of fuel cells energy production in the last 15 years (according to: Office of Energy Efficient and Renewable Energy)

$\mathrm{F} /$ ?uri=CELEX:52020DC0098\&from=EN] as well as many other pro-ecological pursuits of OECD countries aiming to reduce the $\mathrm{CO}_{2}$ emissions to the atmosphere, it can be expected that hydrogen fuel cells will continue to grow in popularity and applications.

Current plans of developing and implementing hydrogen fuel cells prepared by the $\mathrm{FCH}$ initiative (Fuel Cells and Hydrogen) consider a passive and an active adoption variant (Fig. 9). According to the ambitious development plans for the implementation for fuel cell technologies for year 2030 the expected amount of Energy generated using fuel cells is expected to $65 \mathrm{TWh}$ in the energy sector and $70 \mathrm{TWh}$ in the transport sector. Another ambitious step would be achieving 112
TWh of Energy produced by hydrogen fuel cells in the energy sector, 579 TWh of energy produced for heating buildings and up to $675 \mathrm{TWh}$ in the transport sector. The total amount of Energy produced using fuel cells was postulated to increase from $325 \mathrm{TWh}$ in 2015 to $665 \mathrm{TWh}$ in 2030. Whereas in 2050 hydrogen fuel cell energy would be expected to reach a total value of 2251 TWh.

Due to the Energy loss and limited efficiency in the process of production of hydrogen fuel the only justifiable path to using hydrogen to produce electric Energy would be to use hydrogen as a form of energy storage system. Such a strategy would include producing hydrogen fuel using excess electric Energy available from renewable Energy sources during their peak production time [https://

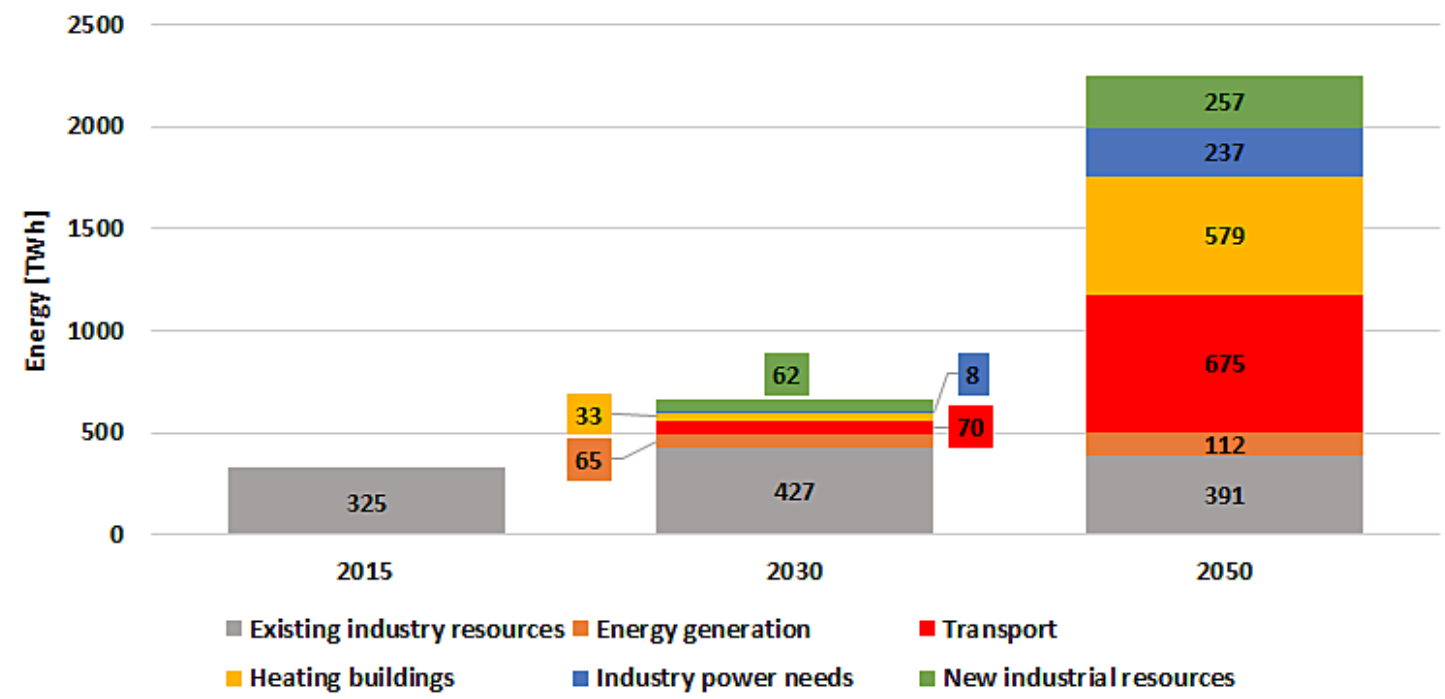

Figure 9. Proposed ambitious growth of using hydrogen in various sectors of the industry [https:// www.fch.europa.eu/sites/default/files/Hydrogen\%20Roadmap\%20Europe_Report.pdf] 

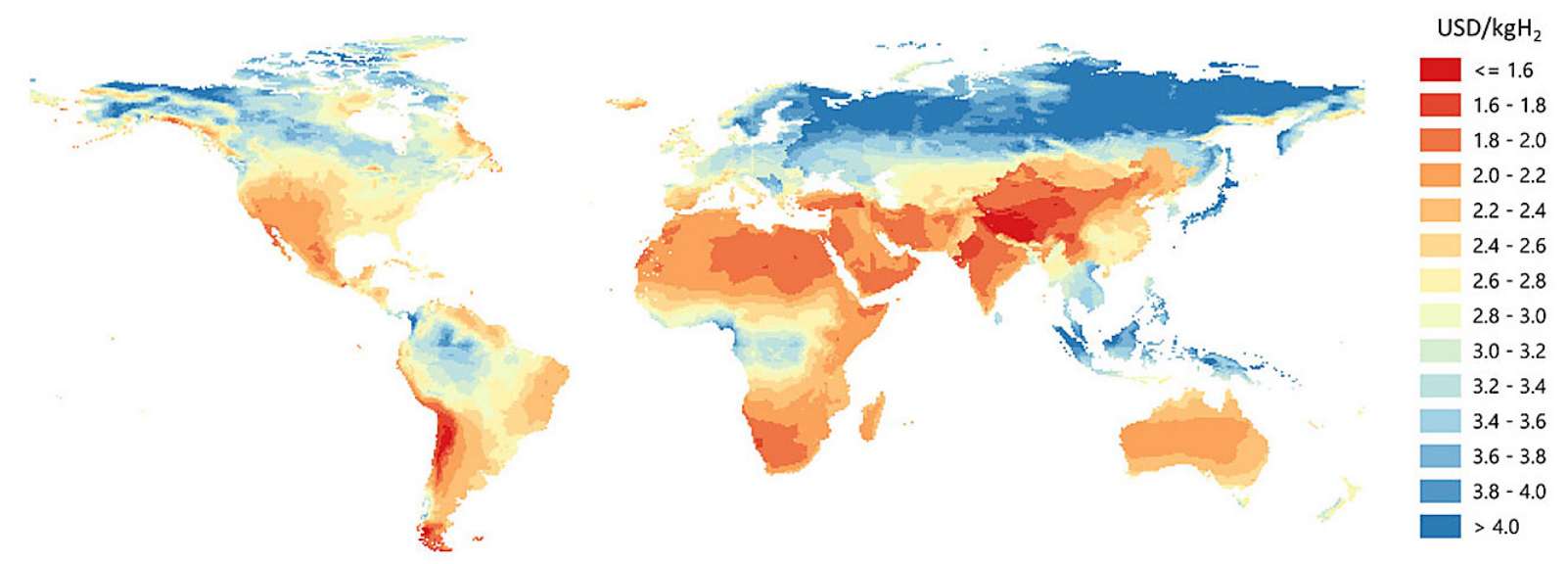

Fig. 10. Map of costs of long term hydrogen fuel production using renewable energy sources [https://www.iea.org/reports/the-future-of-hydrogen]

ec.europa.eu/energy/sites/ener/files/hydrogen_strategy.pdf], which would then be used in the time of increased electric energy demand, which typically takes place in the afternoon hours, which is way past the peak production time for renewables such as solar. As a result of these factors actions and initiatives taken to develop and implement hydrogen fuel cells have been limited in scope by the availability of cheap renewable energy. From an economic standpoint, such a solution is only viable when the cost of energy generation using renewable sources is low enough. The International Energy Agency (IEA) has produced a map with this purpose in mind (Fig. 10), which shows the long term cost of hydrogen fuel production from electric energy generated using renewable energy sources. The current level of hydrogen production is mostly as a side effect of extracting natural gas. Other methods of producing hydrogen include biomass gassing. However, ultimately hydrolysis powered with wind and solar energy is planned to be the end solution for long term hydrogen production [Kakoulaki 2021]. Currently the cost of hydrogen production varies greatly between $\$ 2,50 / \mathrm{kg}$ up to $\$ 6,80 / \mathrm{kg}$, according to the US Department of Energy [https://www.hydrogen.energy.gov/pdfs/20004-cost-electrolytichydrogen-production.pdf]. Yet, S\&P claims that this price needs to fall consistently into the range of $\$ 2-\$ 2,5 / \mathrm{kg}$ in order for hydrogen to become a viable and competitive alternative for fossil fuels [https://www.spglobal.com/platts/en/market-insights/latest-news/electric-power/112020-greenhydrogen-costs-need-to-fall-over-50-to-be-viable-sampp-global-ratings]. This means that the future development and adoption of hydrogen powered solutions, both in rail and automotive sectors, will be intricately linked and dependent on the growth and development of renewable energy production. As of today, production of hydrogen fuel could be justifiable at most in countries close to the equator, as well as in Australia and South America.

\section{CONCLUSIONS}

Thanks to the quick development of hydrogen fuel cell technology as well as the pressure brought on by legislation aimed to reduce atmospheric carbon dioxide emissions new hydrogen solutions and technologies can be found appearing in modern solutions, including in the rail sector. Up until recently, most such innovation was reserved to railbuses and other passenger light rail vehicles, which did not require a large amount of power to be provided by the fuel cells. Even so, in the recent years new solutions have been presented for the use of hydrogen fuel in shunting and freight locomotives, expanding the reach and capabilities of hydrogen-based drive systems. Despite the lower power output provided by the fuel cells in these new drive systems presented by the manufacturers, these vehicles claim to have sufficient power generation to suffice for their designated operations. However, despite the variety of applications shown the widespread adoption of fuel cells in rail transport is still limited by the prohibitive costs of hydrogen fuel production and too high energy costs from renewable sources. It is possible to temporarily patch up the hydrogen supply 
demand using hydrogen obtained using natural gas extraction or produced from biomass, however, these solutions are not sustainable long term and do not scale up enough. Such hydrogen sources can at most serve as intermediary, since they do not fit into the EU strategy regarding zero net emissions of $\mathrm{CO}_{2}$ by 2050. In order to fully exploit the possibilities offered by PEMFC type hydrogen fuel cell based drive systems a sufficient reduction in the hydrogen fuel cost is also necessary. Due to the environmental conditions in most of the EU member states, given current level of technology regarding renewable energy sources and hydrogen production process from hydrolysis, it is impossible to conduct a natural market shift towards a more competitive hydrogen powered transport to supplant conventional fossil fuels. Thus further development of these technologies and solutions will be highly dependent on legal pressure and driven political effort of the EU and the member states, mostly in the form of subsidies and tax reductions for the implementation of hydrogen technologies. The final obstacle in hydrogen fuel achieving economic viability is the production cost, which is tied to the cost of electricity, especially with respect to the cost of conventional fossil fuels. Considering the above, it should be possible to artificially increase the break-even point of the estimated hydrogen fuel price from $\$ 2,50 / \mathrm{kg}$ of hydrogen to a higher value through the use of subsidies for hydrogen production as well as additional taxes or tariffs on fossil fuels, along with further $\mathrm{CO}_{2}$ emission limits.

\section{REFERENCES}

1. Barbir F. 2005. PEM Fuel Cells - Theory and Practice. Chapter 3 - Fuel Cell Electrochemistry. Academic Press, 33-72.

2. Daszkiewicz P., Andrzejewski M., Merkisz-Guranowska A., Gallas D., Stawecka H. 2017. Analiza wybranych napędów alternatywnych stosowanych w autobusach szynowych. Autobusy: technika, eksploatacja, systemy transportowe, 18 .

3. Kakoulaki G., Kougias I., Taylor N., Dolci F., Moya J., Jäger-Waldau A. 2021. Green hydrogen in Europe - A regional assessment: Substituting existing production with electrolysis powered by renewables. Energy Con-version and Management, 228. https:// doi.org/10.1016/j.enconman.2020.113649

4. Oldknow K., Mulligan K., McTaggart-Cowan G. 2021. The trajectory of hybrid and hydrogen technologies in North American heavy haul operations. Railway Engineering Science, 29, 233-247. https:// doi.org/10.1007/s40534-021-00242-1

5. Railway Report 2020, No. 5.

6. Report 2020. Air Quality in Europe - European Environment Agency.

7. Singh K.V., Bansal H.O., Singh D. 2019. A comprehensive review on hybrid electric vehicles: architectures and components. Journal of Modern Transportation, 27, 77-107. https://doi.org/10.1007/ s40534-019-0184-3

8. https://ec.europa.eu/energy/sites/ener/files/hydrogen_strategy.pdf

9. http://www.cprdieselroster.com/Index.htm

10. http://www.trainweb.org/greengoats/bnsf/1205.html

11. https://eur-lex.europa.eu/legal-content/PL/TXT/PDF /?uri=CELEX:52020DC0098\&from $=\mathrm{EN}$

12.https://locomotive.fandom.com/wiki/ RailPower_GG20B

13. https://trainoftheweek.blogspot.com/2010/02/bnsfhh20b.html

14. https:/www.fch.europa.eu/sites/default/files/Hydrogen\%20Roadmap\%20Europe_Report.pdf

15. https://www.hydrogen.energy.gov/pdfs/20004-costelectrolytic-hydrogen-production.pdf

16. https://www.iea.org/reports/the-future-of-hydrogen

17. https:/www.spglobal.com/platts/en/market-insights/ latest-news/electric-power/112020-green-hydrogencosts-need-to-fall-over-50-to-be-viable-sampp-global-ratings

18. https://www.wabteccorp.com/locomotive/ alternative-fuel-locomotives/flxdrive 